National Water Quality Assessment Program

\title{
Comparison of Two Methods for Delineating Land Use Near Monitoring Wells Used for Assessing Quality of Shallow Ground Water
}

Water-Resources Investigations Report 03-4067

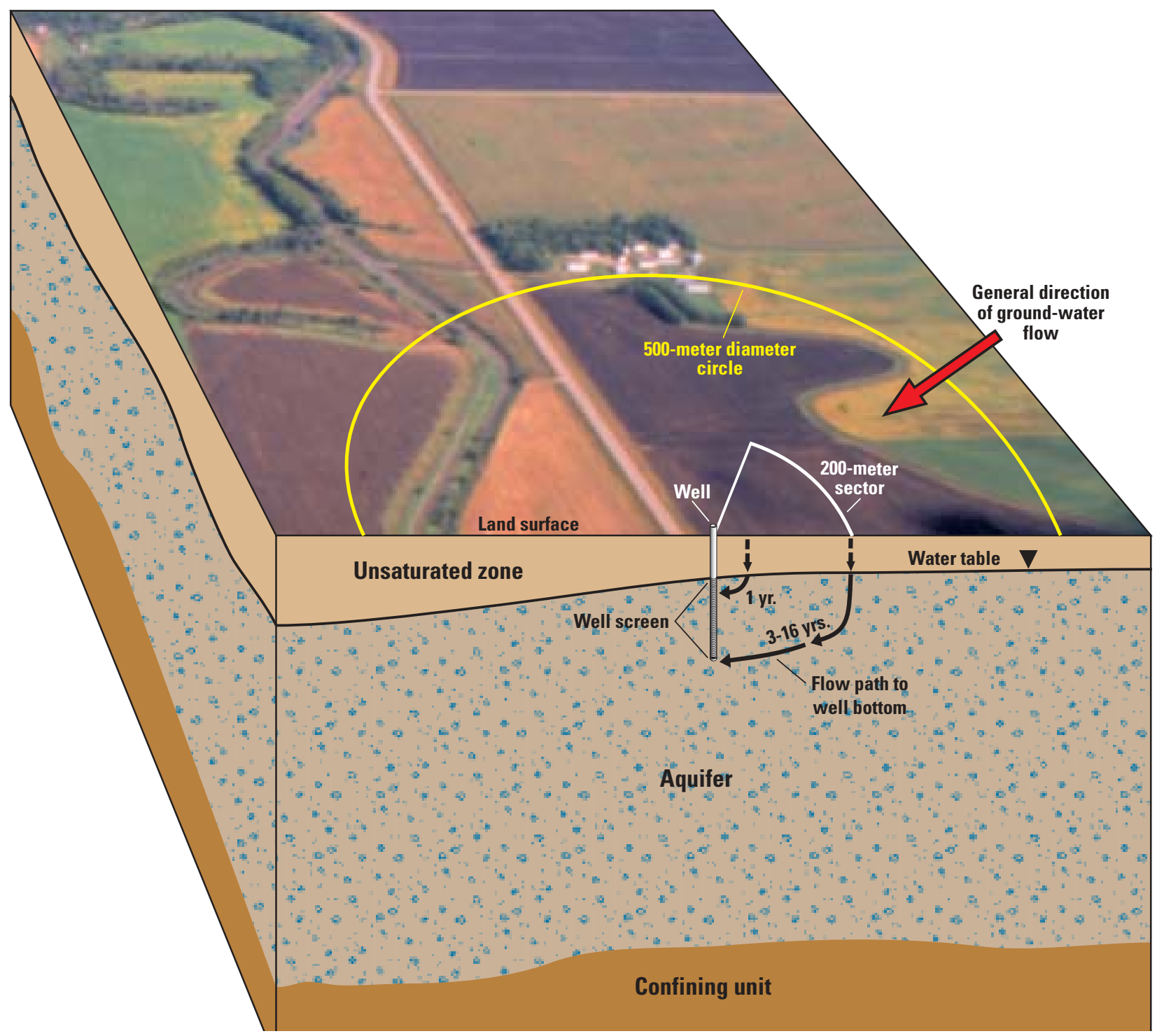

U.S. Department of the Interior

U.S. Geological Survey 
U.S. Department of the Interior

U.S. Geological Survey

\section{Comparison of Two Methods for Delineating Land Use Near Monitoring Wells Used for Assessing Quality of Shallow Ground Water}

By D.L. Lorenz, R.M. Goldstein, T.K. Cowdery, and J.D. Stoner

Water-Resources Investigations Report 03-4067

Contribution from the National Water-Quality Assessment Program 


\title{
U.S. DEPARTMENT OF THE INTERIOR
}

\section{Gale A. Norton, Secretary}

\section{U.S. GEOLOGICAL SURVEY}

\author{
Charles G. Groat, Director
}

Use of firm, trade, and brand names in this report is for identification purposes only and does not constitute endorsement by the U.S. Geological Survey.

For additional information write to:

Chief, NAWOA Program

U.S. Geological Survey

12201 Sunrise Valley Drive, MS 413

Reston, VA 20192

Copies of this report can be purchased from:

\section{U.S. Geological Survey}

\section{Branch of Information Services}

\section{Box 25286, MS 517}

Federal Center

Denver, CO 80225

Information regarding the National Water-Quality Assessment (NAWQA) Program is available on the Internet via the World Wide Web. You may connect to the NAWQA Home Page using the Universal Resource Locator (URL) at: http://wwwrvares.er.usgs.gov/nawqa/nawqa_home.html

Information about the Red River of the North River Basin Project of the NAWQA Program is available at: http://mn.water.usgs.gov/redn/index.html 


\section{FOREWORD}

The U.S. Geological Survey (USGS) is committed to serve the Nation with accurate and timely scientific information that helps enhance and protect the overall quality of life, and facilitates effective management of water, biological, energy, and mineral resources. (http://www.usgs.gov/). Information on the quality of the Nation's water resources is of critical interest to the USGS because it is so integrally linked to the long-term availability of water that is clean and safe for drinking and recreation and that is suitable for industry, irrigation, and habitat for fish and wildlife. Escalating population growth and increasing demands for the multiple water uses make water availability, now measured in terms of quantity and quality, even more critical to the long-term sustainability of our communities and ecosystems.

The USGS implemented the National Water-Quality Assessment (NAWQA) Program to support national, regional, and local information needs and decisions related to waterquality management and policy. (http://water.usgs.gov/nawqa/). Shaped by and coordinated with ongoing efforts of other Federal, State, and local agencies, the NAWQA Program is designed to answer: What is the condition of our Nation's streams and ground water? How are the conditions changing over time? How do natural features and human activities affect the quality of streams and ground water, and where are those effects most pronounced? By combining information on water chemistry, physical characteristics, stream habitat, and aquatic life, the NAWQA Program aims to provide science-based insights for current and emerging water issues and priorities. NAWQA results can contribute to informed decisions that result in practical and effective water-resource management and strategies that protect and restore water quality.

Since 1991, the NAWQA Program has implemented interdisciplinary assessments in more than 50 of the Nation's most important river basins and aquifers, referred to as Study Units. (http://water.usgs.gov/nawqa/nawqamap.html).

Collectively, these Study Units account for more than 60 percent of the overall water use and population served by public water supply, and are representative of the Nation's major hydrologic landscapes, priority ecological resources, and agricultural, urban, and natural sources of contamination.

Each assessment is guided by a nationally consistent study design and methods of sampling and analysis. The assessments thereby build local knowledge about water-quality issues and trends in a particular stream or aquifer while providing an understanding of how and why water quality varies regionally and nationally. The consistent, multi-scale approach helps to determine if certain types of water-quality issues are isolated or pervasive, and allows direct comparisons of how human activities and natural processes affect water quality and ecological health in the Nation's diverse geographic and environmental settings. Comprehensive assessments on pesticides, nutrients, volatile organic compounds, trace metals, and aquatic ecology are developed at the national scale through comparative analysis of the Study-Unit findings. (http://water.usgs.gov/nawqa/natsyn.html).

The USGS places high value on the communication and dissemination of credible, timely, and relevant science so that the most recent and available knowledge about water resources can be applied in management and policy decisions. We hope this NAWQA publication will provide you the needed insights and information to meet your needs, and thereby foster increased awareness and involvement in the protection and restoration of our Nation's waters.

The NAWQA Program recognizes that a national assessment by a single program cannot address all water-resource issues of interest. External coordination at all levels is critical for a fully integrated understanding of watersheds and for cost-effective management, regulation, and conservation of our Nation's water resources. The Program, therefore, depends extensively on the advice, cooperation, and information from other Federal, State, interstate, Tribal, and local agencies, non-government organizations, industry, academia, and other stakeholder groups. The assistance and suggestions of all are greatly appreciated.

Robert M. Hirsch

Associate Director for Water 



\section{CONTENTS}

Abstract

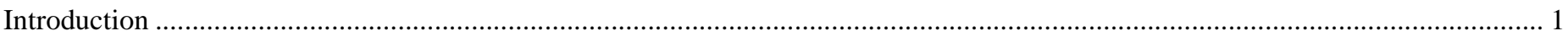

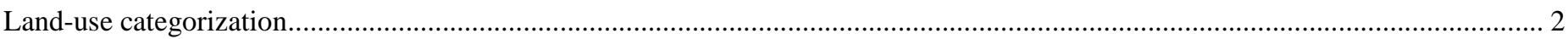

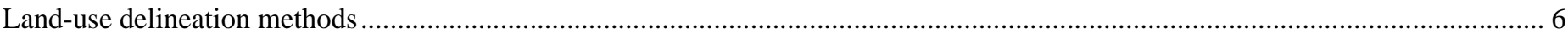

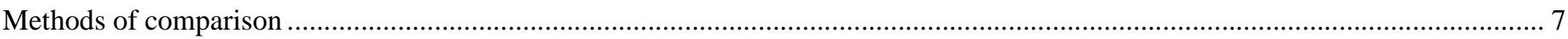

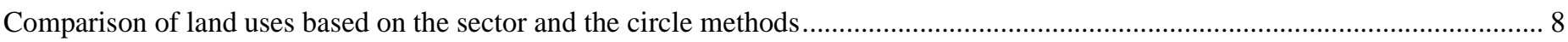

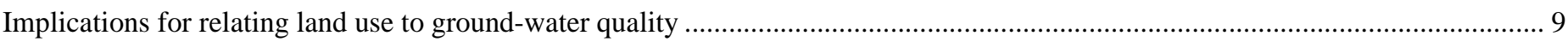

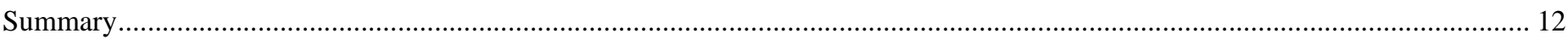

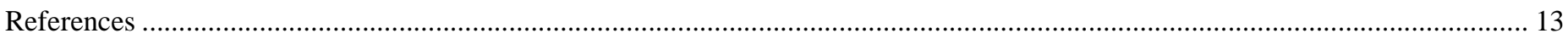

\section{ILLUSTRATIONS}

Figures 1-2. Maps showing:

1. Study area locations, Red River of the North Basin Study Unit ............................................................................ 3

2. Land-use study areas and well networks, Red River of the North Basin Study Unit................................................... 4

Figure 3. Conceptual diagram of two methods for delineating land use of areas contributing recharge to a well screened just

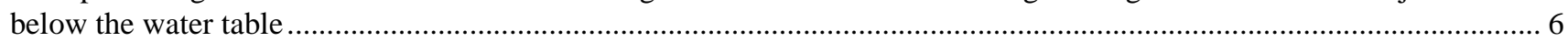

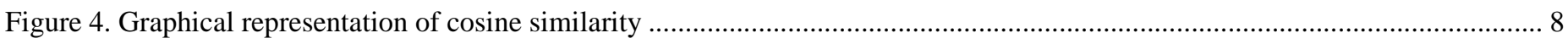

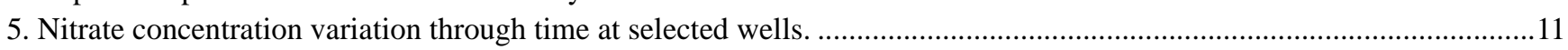

\section{TABLES}

Table 1. Land-use categories aggregated to the common categories used in this study ............................................................... 5

2. Ground-water modeling factors for flow in the study areas, Red River of the North Basin........................................... 7

3. Estimated land-use percentages by the delineation method .................................................................................... 9

4. Similarity values of land use near wells between each method and the general land use for each study area, measured

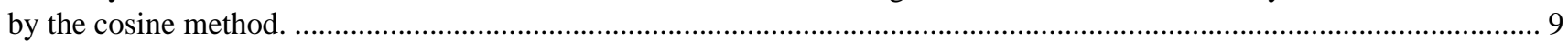

5. Similarity values between land uses near each well within the sector and the 500-meter circle, by study area.................. 10

6. Results of the regression relating land use to nitrate concentration. ............................................................................11

\section{CONVERSION FACTORS AND ABBREVIATIONS}

$\begin{array}{lcl}\text { Multiply metric unit } & \underline{\text { by }} & \text { to obtain inch-pound unit } \\ \text { meter }(\mathrm{m}) & 3.281 & \text { foot } \\ \text { kilometer }(\mathrm{km}) & 0.6214 & \text { mile } \\ \text { square kilometer }\left(\mathrm{km}^{2}\right) & 0.3861 & \text { square mile }\end{array}$

Abbreviated water quality units: Chemical concentrations are given in milligrams per liter (mg/L), a unit expressing the concentration of chemical constituents in solution as mass (milligrams) per unit volume (liter) of water. 


\section{ACKNOWLEDGMENTS}

\section{TECHNICAL REVIEWERS}

Geoffrey Delin, Hydrologist; U.S. Geological Survey, Mounds View, Minnesota Bernard T. Nolan, Research Hydrologist, U.S. Geological Survey, Reston, Virginia

\section{EDITORIAL AND GRAPHICS}

Carol Anderson, Editor, U.S. Geological Survey, Lakewood, Colorado Ginger Amos, Editor, U.S. Geological Survey, Mounds View, Minnesota Robert Borgstede, Illustrator, U.S. Geological Survey, Mounds View, Minnesota Gerhard Kuhn, Hydrologist, U.S. Geological Survey, Lakewood, Colorado

\section{APPROVING OFFICIAL}

George Garklavs, Reports Improvement Advisor, St. Paul, Minnesota 


\title{
Comparison of Two Methods for Delineating Land Use Near Monitoring Wells used for Assessing Quality of Shallow Ground Water
}

\author{
By David L. Lorenz, Robert M. Goldstein, Timothy K. Cowdery, and Jeffrey D. Stoner
}

\section{ABSTRACT}

Two methods were compared for delineating land use near shallow monitoring wells. These wells were used to assess the effects of agricultural cropland on the quality of recently recharged ground water in two sand and gravel aquifers located near land surface. The two methods for delineating land use near wells were (1) the sector method, which used potentiometric-surface maps to estimate average flow direction and a ground-water-flow model to estimate maximum length of contributing area to the monitoring well within an upgradient sector; and (2) the circle method, which used a 500meter radius circle around the well based on a national empirical analysis. Land uses were compiled for 29 wells in each of two surficial aquifers in the Red River of the North Basin within the area defined by each method. Land use near each well was interpreted from orthorectified photographs and site inspection for both delineation methods. Land use near individual wells characterized by each method varied greatly, which can affect the results of statistical correlations between land use and water quality. Land use determined by the circle method related more closely to the land use for each entire study area. Land use determined by the sector method (within 200 meters from the wells) compared more favorably to ground-water quality based on nitrate concentrations. The maximum length of contributing areas to wells estimated in this study may be of value for other studies of unconsolidated sand and gravel aquifers with similar hydrogeological characteristics of permeability, water-table slopes, recharge, and depth to water. The additional effort required for estimating the model delineation of land use and land cover for the sector method must be weighed against the improved confidence in statistical correlation between land use and the quality of shallow ground water. Improved scientific confidence and understanding of relations between land use and quality of ground water may encourage more effective implementation of land and water management for protecting water quality.

\section{INTRODUCTION}

Goals of the U.S. Geological Survey's (USGS) National Water-Quality Assessment (NAWQA) Program are achieved through investigation of the Nation's most important river basins and aquifer systems, which are referred to as "Study Units" (Gilliom and others, 1995). These Study Units are distributed throughout the Nation and encompass diverse hydrologic settings. National synthesis of NAWQA data, based on aggregation of comparable information obtained from the Study Units, is a major component of the program. This effort focuses on selected water-quality topics (water chemistry and aquatic biological communities) using nationally consistent information and methods.
Comparative studies (1) explain differences and similarities in the status of water quality among Study Units, and (2) identify changes, trends, and associated causes.

The ground-water component of the NAWQA Program assesses ground-water quality at three spatial scales: (1) in the major aquifers of the Study Unit, surveys assess water quality commonly used for drinking water, (2) in specific land-use areas, studies assess the effects of land use on the quality of recently recharged shallow ground water associated with a specific and hydrogeologic conditions, and (3) along a specific ground-water flow transect, studies examine the relations among land use, groundwater flow, contaminants, and surface/ground-water interactions (Gil- liom and others, 1995). Analysis of results from geographic nesting of a land-use study within a survey of a major aquifer can provide useful insights into future effects of land-use activities on the quality of drinking water.

The land-use studies are used to evaluate the quality of recently recharged ground water (generally less than 10 years old) in regions that represent the intersection of a targeted land use and an aquifer of interest. The targeted land use may be a specific group of crops and associated agricultural practice or residential and commercial development of a certain age (Squillace and Price, 1996). The aquifers of interest typically are unconfined and near the land surface. These studies attempt to determine 
what land-use-derived contamination is reaching the youngest ground water in the area.

Preliminary national synthesis of results from various land-use studies completed within the first 20 Study Units indicated a problem correlating the overall targeted land use with the observed ground-water quality (Bernard T. Nolan, U.S. Geological Survey, oral commun., 2000). The problem was that the methods for delineating land use within a targeted land-use area were not finalized and there was some variability in this delineation among the Study Units. Many Study Units targeted agricultural land. The targeted agricultural land-use area generally included a mixture of a specific cropland group and non agricultural land, such as forest or wetland. Individual investigators may or may not have included the non agricultural land within the definition of the land-use study area. Well locations were randomly selected throughout the targeted land-use area and hydrogeologic setting specific to the Study Unit using an equal-area grid method and computer program (Scott, 1990). For example, given the same targeted land-use area for well placement, one investigator may have classified the area as 40-percent cropland, whereas another could have found 95-percent cropland, depending on the geographic scale at which the land use was implemented. That variability in interpretations resulted in the problem correlating the targeted land use to observed water quality from those wells. After the preliminary national synthesis analysis identified this problem, guidance was developed to foster more consistent land-use delineation around the monitoring wells regardless of the interpretation of overall landscapes across the Nation. Although draft NAWQA guidance and recommendations for determining land use near individual wells were available before 1998, the procedures were not finalized until published in Koterba (1998). The Red River of the North Study Unit characterized land use at the study areas and near the individual wells (Cowdery, 1997) before finalizing the revised methods presented in Koterba (1998).

This report (1) compares two methods of delineating land use around monitoring wells and (2) examines the applicability of each method for assessing land-use effects on the quality of shallow ground water. For reference in this report, the approach used by the Red River of the North Study Unit (Cowdery, 1997) is referred to as the "sector method" and the national approach (Koterba, 1998) is referred to as the "circle method". Land uses delineated by the two methods are compared at two of the three spatial scales used in NAWQA ground-water studies: (1) targeted land use within specific study areas compared to the land use near individual wells determined by each method, and (2) comparison of land use near individual wells determined by each method. Applicability of each method for evaluating the quality of shallow ground water is accomplished by evaluating the correlations of nitrate concentrations with land use relative to the spatial scales of the two methods.

The Red River of the North Basin Study Unit encompasses $90,000 \mathrm{~km}^{2}$ in Minnesota, North Dakota, and South Dakota (fig. 1). Within the Study Unit, the hydrogeologic settings for the ground-water land-use study areas were the two largest surficial aquifers: the Sheyenne Delta and the Otter Tail Outwash (Cowdery, 1997). The Sheyenne Delta is an underflow delta and consists of fine and very fine sand in the southwest grading to silt and clay in the northeast. The Otter Tail Outwash is an intramorainal outwash plain consisting primarily of fine to coarse sand. Typical depth to the water table is about $1.5 \mathrm{~m}$ in the Sheyenne Delta and about $4.5 \mathrm{~m}$ in the Otter Tail Outwash. Although the Study Unit is mostly agricultural (Lorenz and Stoner, 1996), cropping patterns differ throughout the area. In the Sheyenne Delta study area, the dominant crops were corn, hay, and sunflowers and grazing was a major land use (about 25 percent of the area). In the Otter Tail Outwash study area, the major crops were corn, hay, beans, with some potatoes. Much more cropland is irrigated in the Otter Tail Outwash study area than in the Sheyenne Delta study area. For additional information see Stoner and others (1993), Lorenz and Stoner (1996), and Cowdery (1997).

The targeted land use was agricultural, which for this study meant that at least 80 percent of the land use of the study areas was cropland, pasture, or grazing, or contained the infrastructure necessary to support those activities (farmsteads and roads). The study areas that were selected are shown in figure 2 . The land use within each study area was not completely homogeneous. Within an area generally regarded as agricultural, there can be wetlands, lakes, forests and small villages. Although the general land use was agricultural, other land uses may account for up to 20 percent of the total area.

\section{LAND-USE CATEGORIZATION}

Digital land-cover and land-use (hereinafter referred to as "land use") data (LUDA) are available from the U.S. Geological Survey (1986). These data were augmented by direct-observation field surveys from 1993-95 and interpretation of aerial photographs (1987-93). The Anderson Level II (Anderson and others, 1976) classification system was used as a basis to define land-use categories for these data.

The Anderson Level II classification system was modified for use in 


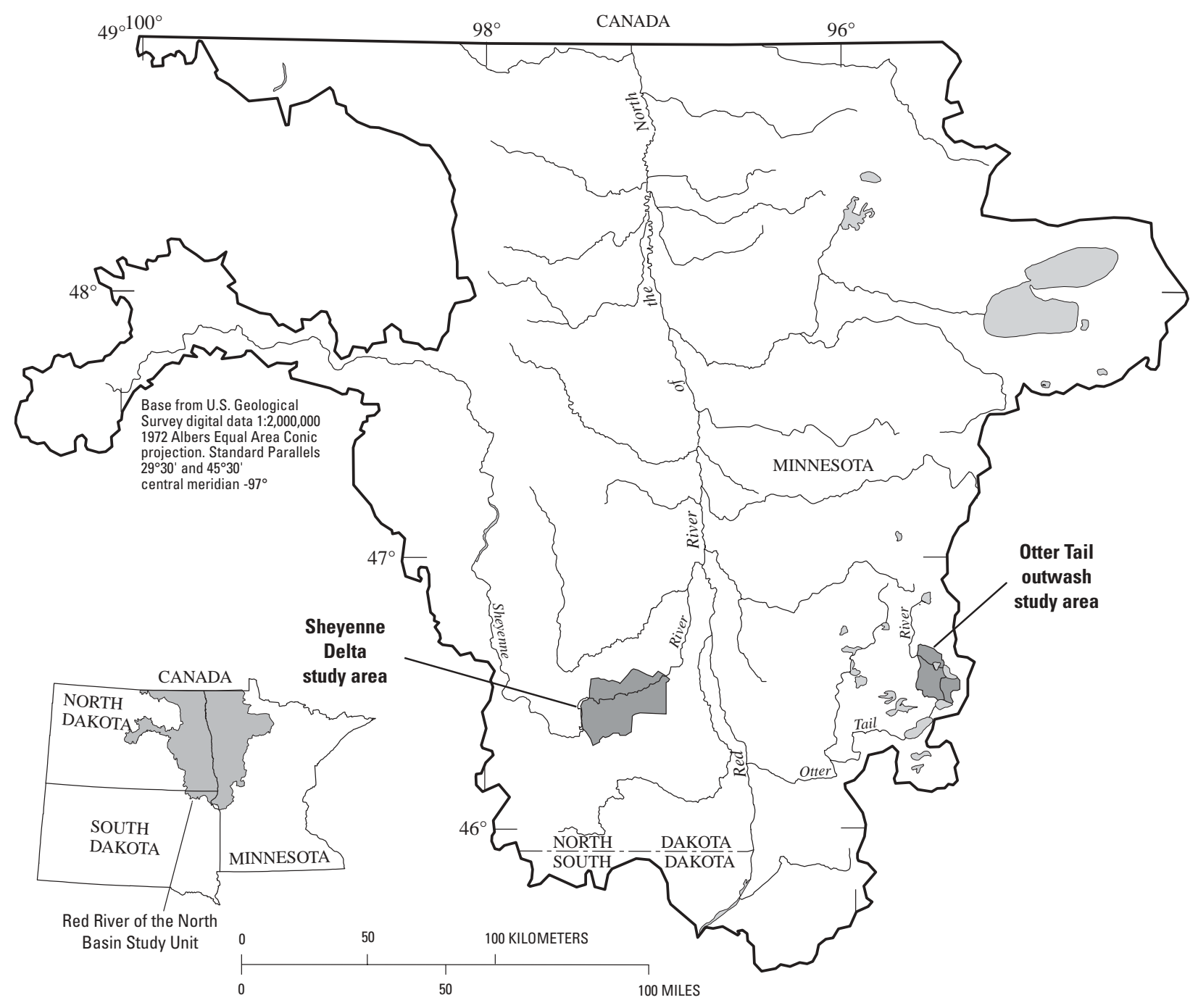

Figure 1. Study area locations Red River of the North Basin Study Unit.

the land-use study areas in the Red River of the North Study Unit. Agricultural land class 21 (cropland and pasture) (Anderson and others, 1976) was divided into four categories: dryland cropland, irrigated cropland, pasture, and hay. A fifth category was added for the Sheyenne National Grassland to better define the boundary of that area.

Koterba (1998) identified hundreds of detailed land-use categories for a national (NAWQA) system using the broad categories of agricultural, urban, mining, and general. Examples in the general category include open water, forests, and wet- lands. The agricultural land use includes separate subcategories for each possible crop or type of livestock. That system also uses a special code to indicate whether the land is irrigated. The detail provided by the NAWQA system was designed to enable correlation of the occurrence of specific contaminants associated with a unique crop or land use.

In this study, 37 categories from Koterba (1998) were used to define the land use delineated by the circle method in the study area. Earlier, the Red River of the North Study Unit defined 15 land-use categories (Cowdery, 1997); however, the two sets of land-use categories were not entirely compatible. To make comparisons between the land uses delineated by the two methods, a common set of nine land-use categories was constructed (table 1).

The land use for each study area was compared to the land use near each randomly placed well within that study area. Open water was originally not considered part of the study area because most open water (streams and lakes) were assumed to not contribute recharge, and therefore, not affect ground-water quality. Concentrated livestock also were not part of the original classification because none 


\section{Sheyenne Delta Study Area}

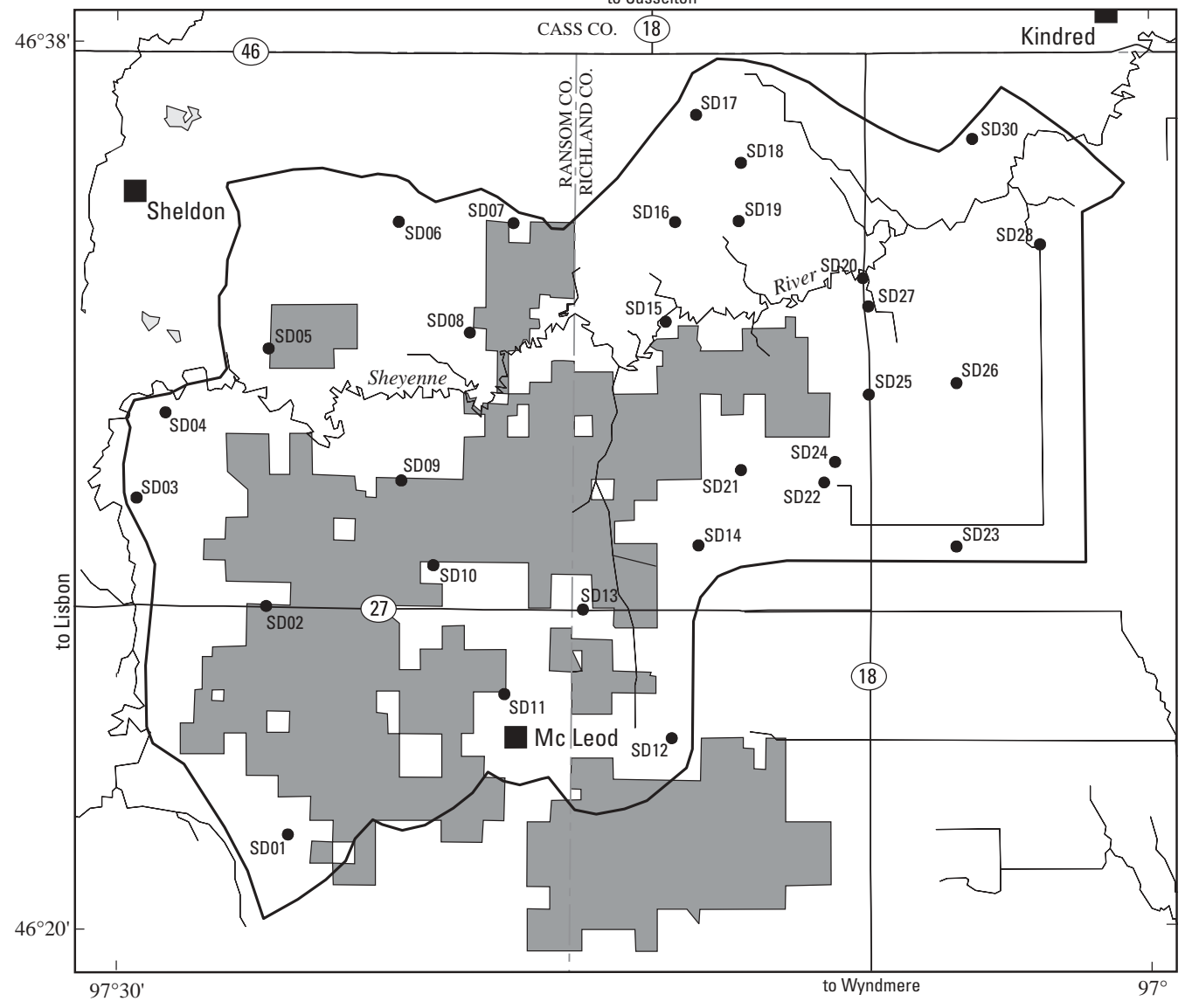

\section{EXPLANATION}

National Grassland (Not a part of the Sheyenne Delta Study Area)

- $^{\text {OT20 Well location and well number }}$

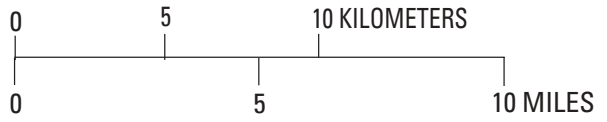

Base from U.S. Geological Survey digital data 1:100,000, 1976-1986 Albers Equal Area Conic projection

Standard parallels $29^{\circ} 30^{\prime}$ and $45^{\circ} 30^{\prime}$

central meridian $-97^{\circ}$

Figure 2. Land-use study areas and well networks, Red River of the North Basin Study Unit.
Otter Tail Outwash Study Area

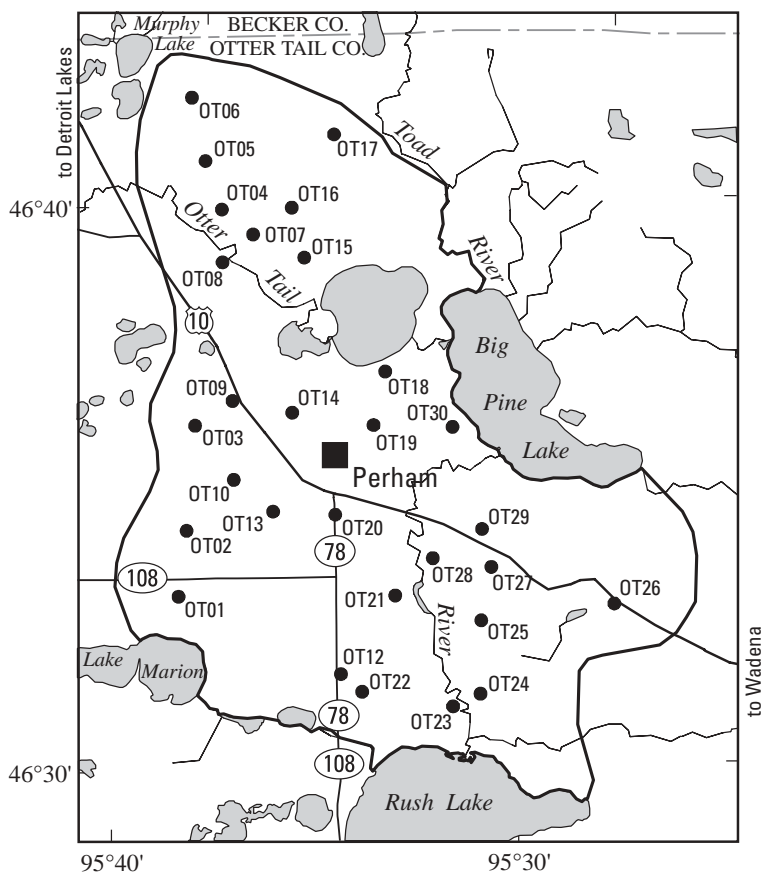


Table 1. Land-use categories aggregated to the common categories used in this study

\begin{tabular}{|c|c|c|}
\hline $\begin{array}{l}\text { Red River of the North } \\
\text { land-use categories }\end{array}$ & $\begin{array}{c}\text { Common land-use categories } \\
\text { (this study) }\end{array}$ & National (NAWQA) land-use categories \\
\hline Dryland cropland & \multirow[t]{13}{*}{ non-irrigated cropland } & cropland, nonproductive \\
\hline \multirow[t]{12}{*}{ Hay } & & cropland, barren \\
\hline & & alfalfa hay or feed \\
\hline & & alfalfa seed \\
\hline & & field corn \\
\hline & & corn, unknown use \\
\hline & & small grain, unknown \\
\hline & & oats \\
\hline & & potatoes \\
\hline & & sunflowers \\
\hline & & sorghum \\
\hline & & soybeans \\
\hline & & wheat \\
\hline Irrigated cropland & irrigated cropland & special code for any of the above categories \\
\hline Grazing, grassland, or pasture & \multirow[t]{3}{*}{ grassland and pasture } & general rangeland \\
\hline Grazing, mixed shrub and field & & horses, pasture \\
\hline National grassland & & mixed domestics, pasture \\
\hline Deciduous forest & \multirow[t]{5}{*}{ forest } & coniferous, managed \\
\hline Evergreen forest & & coniferous, unmanaged \\
\hline \multirow[t]{3}{*}{ Mixed forest } & & deciduous, managed \\
\hline & & deciduous, unmanaged \\
\hline & & mixed forest, unmanaged \\
\hline \multirow[t]{2}{*}{ Nonforest wetland } & \multirow[t]{3}{*}{ wetlands } & general wetland \\
\hline & & lacustrine wetland \\
\hline Forested wetland & & riverine wetland \\
\hline \multirow[t]{2}{*}{ Roadway transportation } & \multirow[t]{2}{*}{ transportation } & road \\
\hline & & railway \\
\hline \multirow[t]{2}{*}{ Farmstead } & \multirow[t]{2}{*}{ farmstead } & agricultural related \\
\hline & & development \\
\hline \multirow{2}{*}{$\begin{array}{l}\text { Urban residential } \\
\text { Urban commercial }\end{array}$} & \multirow[t]{2}{*}{ urban } & urban, residential \\
\hline & & urban, commercial \\
\hline 1 & open water & open water \\
\hline \multirow[t]{5}{*}{1} & \multirow[t]{5}{*}{ concentrated livestock } & feedlot or confined \\
\hline & & domestic livestock \\
\hline & & cattle, beef \\
\hline & & cattle, dairy \\
\hline & & swine \\
\hline
\end{tabular}

\footnotetext{
${ }^{1}$ Category not used in original study
} 
were identified in the land-use and land-cover data collected in the 1970's. Open water and concentrated livestock were included as categories for this study because they do occur within the 500-m circles around wells.

\section{LAND-USE DELINEATION METHODS}

In the land-use studies for the Red River of the North Study Unit, the land-use area (with its associated land uses) contributing recharge to a well was estimated using ground-water models that determine traveltimes of water to a well under natural flow conditions (Cowdery, 1997). The method, referred to as the "sector method", produced either a pieshaped sector of the land upgradient from the well if the direction of ground-water flow was known, or a circle of land surrounding the well if the direction of flow could not be determined. The length of the radius of each sector (or circle if direction was not known) was determined using a ground-water model to backtrack water from the bottom of the screened interval to the water table (path $\mathrm{b}$ in figure 3). The sector shape was chosen as a simple approximation of the zone of influence for potential

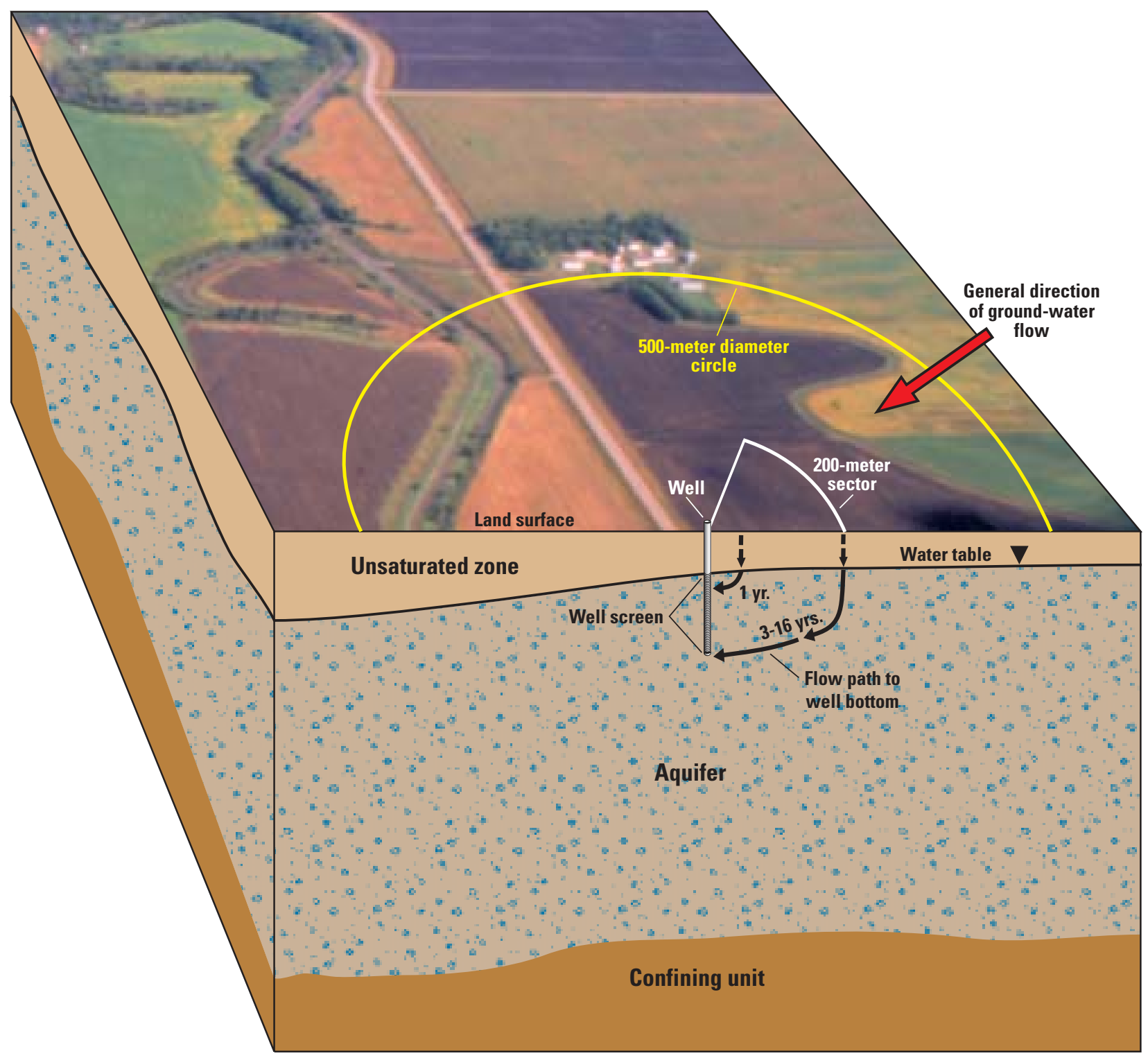

Figure 3. Conceptual diagram of two methods for delineating land use of areas contributing recharge to a well screened just below the water table. [3-16 yrs. is the range in estimated maximum time for a water particle to travel from water table to bottom of monitoring well.] 
recharge. A 90-degree angle was selected to account for seasonal uncertainty in the regional groundwater flow direction. In low watertable gradient areas, the radii were 50 and $150 \mathrm{~m}$, and in high water-table gradient areas were 125 and $200 \mathrm{~m}$ in the Sheyenne Delta and the Otter Tail Outwash study areas, respectively (table 2). These radii represent distance of recharge influence estimates of the maximum for each study area. Table 2 is a summary of the hydrologic factors used in ground-waterflow models to estimate the radii of sectors for the study areas (Cowdery, 1997). The model estimates of traveltime within the saturated zone compared favorably with ages of ground water measured by chlorofluorocarbon dating methods of selected ground-water samples (Stoner and others, 1998).

An evaluation of previous studies by Koterba (1998) suggested that the best compromise for defining land- use characteristics around monitoring wells in a wide variety of hydrogeologic settings across the Nation would be a circular buffer with a 500-m radius from the well. Koterba (1998) reported that for many study areas, the direction of ground-water flow and hydraulic characteristics of the aquifer may not be well defined or known. Figure 3 highlights the major differences between the methods proposed by Koterba (1998) and that used in the Red River of the North for a $200 \mathrm{~m}$ radius sector. For well sites where the general direction of ground-water flow is known, the 90-degree sectors are expected to better estimate the contributing area of recharge and associated land use for these wells than the 500-m circles used as buffers for national statistical comparisons.

\section{METHODS OF COMPARISON}

To determine how well the sector and circle methods characterized the general land use for the two study areas, the land use for all wells for each study area was computed by calculating the mean of each percentage land use for each method. Those means were compared to the land-use composition of each respective study area. Land use from each well was determined by the two methods, giving one similarity comparison for each well in each study area. If both methods measure the same land uses, the similarity values should be classed as very similar.

Several methods can be used to calculate similarity values for comparing percentage data that belong to mutually exclusive and exhaustive categories. This means that the percentages of the categories for an observation (land use within a circle or sector) always sum to 100 percent. For this report, the categories are those listed in table 1 (common landuse categories). One difficulty with percentage data is that the values are

Table 2. Ground-water modeling factors for flow in the study areas, Red River of the North Basin [modified from Cowdery, 1997; m, meter; m/y, meter per year; WT, water table.]

\begin{tabular}{|c|c|c|c|}
\hline \multirow[b]{2}{*}{ Factor } & \multicolumn{2}{|c|}{ Study Area } & \multirow[b]{2}{*}{ Data Source } \\
\hline & Sheyenne Delta & Otter Tail Outwash & \\
\hline Aquifer thickness (m) & $19.5-26.5$ & $13.4-14.9$ & well logs \\
\hline Porosity & 0.35 & 0.25 & estimated from grain-size distribution \\
\hline Effective recharge rate $(\mathrm{m} / \mathrm{y})$ & 0.076 & 0.177 & model calibration \\
\hline Horizontal hydraulic conductivity (m/day) & $1.5-3.0$ & $31-73$ & aquifer tests and model adjustments \\
\hline Ratio of horizontal to vertical hydraulic conductivity & 10 & 5 & assumed from inspection of core samples \\
\hline \multicolumn{4}{|c|}{ Low water-table gradient conditions } \\
\hline Gradient range (dimensionless) & $0.0008-0.0015$ & $0.00019-00044$ & water table map \\
\hline Number of wells in low gradient conditions & 26 & 21 & -- \\
\hline Radius of influence for $1.5 \mathrm{~m}$ depth below WT (m) & $21-24$ & $85-111$ & model results \\
\hline Maximum traveltime (years) & 8.0 & 2.5 & model results \\
\hline Radius of influence for $3 \mathrm{~m}$ depth below WT (m) & $40-49$ & $159-229$ & model results \\
\hline Maximum traveltime (years) & 15.6 & 4.8 & model results \\
\hline Radius chosen to characterize land use (m) & 50 & 150 & model results \\
\hline \multicolumn{4}{|c|}{ High water-table gradient conditions } \\
\hline Gradient range & $0.0015-0.011$ & $0.00077-0.0017$ & water table maps \\
\hline Number of wells in high gradient conditions & 3 & 8 & -- \\
\hline Radius of influence for $1.5 \mathrm{~m}$ depth below water & $117-120$ & $168-192$ & model results \\
\hline Maximum traveltime (years) model & 7.6 & 2.5 & model results \\
\hline Radius chosen to characterize land use (m) & 125 & 200 & model results \\
\hline
\end{tabular}


not independent; if the value in one category increases, then values within the other categories must decrease. Because of the relations of these data, the usual methods of comparison (such as computing Euclidean distances) are not appropriate. One appropriate method is to describe the difference between two observations by the angle between them (Philip and Watson, 1988). In this comparison, the particular advantage for using angles is that they reduce edge effects-differences between small values are downweighted using this method compared to Euclidean distances (fig. 4). Thus, this method emphasizes the differences between the major landuse categories in the observations. It is more common to express the angle between points as a similarity in terms of the cosine of the angle. Values of the cosine range from 1 (identical composition) to 0 (no categories in common). The cosine of the angle between observations then becomes a measure of similarity, analogous to a correlation coefficient in correlation analysis. The cosine of the angle hereinafter will be referred to as the "similarity value".

The similarity value between observations is given by: $\mathrm{S}_{\mathrm{kl}}=\Sigma \mathrm{c}_{\mathrm{ik}} * \mathrm{c}_{\mathrm{il}} /\left(\Sigma \mathrm{c}_{\mathrm{ik}}^{2} * \Sigma \mathrm{c}_{\mathrm{il}}^{2}\right)^{1 / 2}$, where $S_{\mathrm{kl}}$ is the similarity value between observation $\mathrm{k}$ and $\mathrm{l}$,

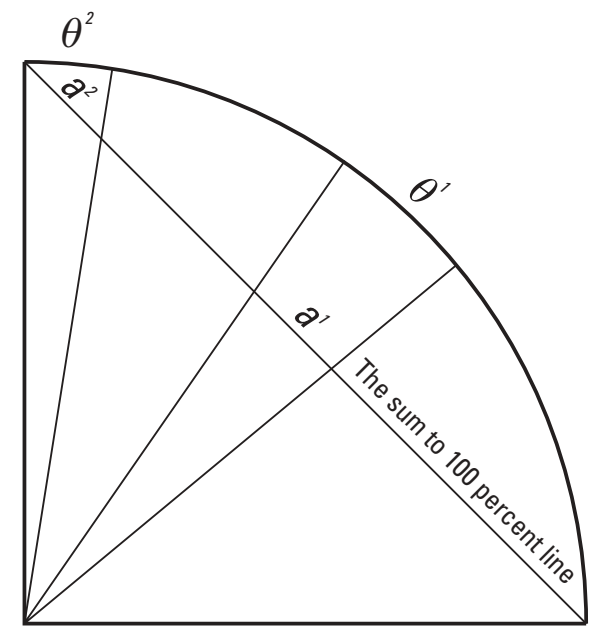

$\mathrm{c}_{\mathrm{ik}}$ and $\mathrm{c}_{\mathrm{il}}$ are the percentage values for category i for observations $\mathrm{k}$ and $\mathrm{l}$, and the summation is performed over all categories.

Observations were classified as "very similar" if the similarity value was greater than 0.95 (corresponding to angles less than 18 degrees). Observations were classified as "different" if the similarity value was less than 0.75 (corresponding to an angle greater than 41 degrees) and "similar" if between 0.95 and 0.75 . These criteria are round numbers close to $95^{\text {th }}$ and $50^{\text {th }}$ (median) percentile values of a cumulative cosine distribution (0.948 and 0.731).

\section{COMPARISON OF LAND USES BASED ON THE SECTOR AND CIRCLE METHODS}

The process of randomly selecting well locations within the targeted land use of the study area was assumed to produce a representative sampling of land use near the selected well. Targeted land uses within the two study areas (table 3) were compared to the land use near each well as determined by both methods. The general land use represents all of the land uses within each study area, determined by using the augmented LUDA data.

The results of the comparison between the mean percentage for each method and the general land use for

Figure 4. Graphical representation of cosine similarity. [The percentage difference $\mathrm{a}^{1}$ and $\mathrm{a}^{2}$ are projected onto an arc giving angular differences $\theta^{1}$ and $\theta^{2}$. Line segments $a^{1}$ and $\mathrm{a}^{2}$ are equal in length (represent the same percentage difference). But, $\theta^{1}$ is greater than $\theta^{2}$. This demonstrates the reduction in edge effect using cosine similarity]. the study area are summarized in table 4. The sector method for the Sheyenne Delta has a similarity value less than all other values because the area of the sectors in the Sheyenne Delta is relatively small, and land use categorized as "transportation" composes a substantial percentage of the area of the sector. All other similarity values are greater than 0.95 , indicating similar comparison.

The similarity values for comparing land-use delineation (sectors and 500 -m circles) varied greatly. For the Sheyenne Delta study area, similarity values ranged from 0.17 to 0.99 , whereas the range of similarity values for wells on the Otter Tail Outwash study area was slightly greater, ranging from 0.10 to 0.99 (table 5). The two methods produced similar results. There would be no wells with similarity values less than 0.75 . In the Sheyenne Delta, however, 13 of 29 similarities were less than 0.75 , and in the Otter Tail Outwash, 11 of 29 similarities were less than 0.75 , indicating that the land use determined by the two methods for the same well could be quite different.

Approximately 40 percent of the comparisons between the two methods produced low similarity values that can be attributed to the large differences in areas delineated by the two methods. The areas included in the 90-degree sectors ranged from 0.25 to 1.56 percent (median of 0.25 percent) of the total area within a 500$m$ circle for the Sheyenne Delta well sites. The areas included in the 90degree sectors ranged from 2.25 to 4.00 percent (median of 2.25 percent) of the total area within a 500-m circle for the Otter Tail Outwash well sites. The largest median of 2.25 percent represents a difference in land area of $767,700 \mathrm{~m}^{2}$ between the two delineation methods. The difference in the median sector areas between study areas was only $15,700 \mathrm{~m}^{2}$. The location of the sector within the 500-m 
Table 3. Estimated land-use percentages for the study areas by the delineation method

[Values for circle and sector methods are the means for each category from all 29 wells in each study area]

\begin{tabular}{|c|c|c|c|c|c|c|}
\hline \multirow[b]{2}{*}{ Land use } & \multicolumn{3}{|c|}{ Sheyenne Delta study area } & \multicolumn{2}{|c|}{ Otter Tail Outwash study area } & \multirow[b]{2}{*}{ Sector } \\
\hline & Study-area target & Circle & Sector & Study-area target & Circle & \\
\hline Non-irrigated cropland & 60 & 49 & 37 & 46 & 49 & 43 \\
\hline Irrigated cropland & 4 & 3 & 1 & 27 & 21 & 18 \\
\hline Grassland and pasture & 25 & 32 & 26 & 8 & 3 & 13 \\
\hline Forest & 5 & 10 & 2 & 11 & 11 & 7 \\
\hline Wetlands & 4 & 0 & 0 & 4 & 5 & 0 \\
\hline Transportation & 1 & 4 & 32 & 1 & 4 & 9 \\
\hline Farmstead & 1 & 2 & 3 & 2 & 2 & 7 \\
\hline Urban & 0 & 0 & 0 & 1 & 2 & 3 \\
\hline Open water & 0 & 0 & 0 & 0 & 1 & 0 \\
\hline Concentrated livestock & 0 & 0 & 0 & 0 & ${ }^{1} 0$ & 0 \\
\hline Total & 100 & 100 & 101 & 100 & 98 & 100 \\
\hline
\end{tabular}

${ }^{1}$ Concentrated livestock was 3 percent at two wells

circle also could have a significant effect on the comparison of resulting land use between the two methods. For example, in figure 3, by rotating the sector 180 degrees in any direction, transportation would be part of the delineated land use.

\section{IMPLICATIONS FOR RELATING LAND USE TO GROUND-WATER QUALITY}

For agricultural areas, land use is assumed to be a reasonable surrogate for the timing and intensity of chemicals applied to the land. The potential for any chemical to reach shallow ground water depends on the hydrogeology, weather conditions, agricultural practices, and characteristics of the chemical. However, the land-use studies are also a means for understanding how land use, chemical application, and hydrogeologic conditions affect water quality spatially and temporally. Use of chemicals in agricultural areas usually is consistent with crop type. Where the same land use (cropping pattern and chemical use) occurs across several Study Units, the effects of hydrogeologic conditions can be examined by determining the quality of the shallow ground water.

Shallow ground-water quality in the two study areas was significantly different (Cowdery, 1997) even though the general land use was similar (similarity value is 0.87 ). Significant differences were observed in median concentrations of oxygen, nitrate, and ammonia. The number of herbicides detected was different, as were the median total pesticide concentrations. Cowdery (1997) attributed the differences in water quality to differences in hydrogeology, rainfall, and biological activity as well as land use, and states that these factors magnified the differences in water quality that may have been expected from land use alone.

Because the two methods are expected to measure the land use near each well that affects ground-water quality, the application of one or the

Table 4. Similarity values of mean land use near wells for each method and the general land use for each study area, measured by the cosine method

\begin{tabular}{ccc}
\hline Study area & Sector & Circle \\
\hline Sheyenne Delta & 0.80 & 0.98 \\
Otter Tail outwash & 0.96 & 0.99 \\
\hline
\end{tabular}

other method will change the perspective of such an analysis. About 45 percent of the similarity values between the two methods from the Sheyenne Delta study area and 38 percent from the Otter Tail Outwash study area are different. For the Sheyenne Delta study area, one reason for the differences between the two methods results from large areas of land use near some wells that are not representative of general land use. In particular, several wells are located near the periphery of the Sheyenne National Grassland (fig. 2 ). The 500-m circles include relatively large areas that are grassland, grazing, forests, or wetlands, which are the dominant land uses of the Sheyenne National Grassland. The short radii of influence used for the Sheyenne Delta sectors also resulted in a larger percentage of land area classified as "transportation" (a road may account for 5 to 10 percent of the area of a sector). For the Otter Tail Outwash study area, the larger dissimilarities are caused by smaller scale heterogeneities that affect the land use near some wells but not others.

The large dissimilarities between the methods can lead to misinterpretation of the relation of land use to water quality. Theoretically, the sector method should provide the more accurate determination of the land area 
Table 5. Similarity values (cosine of the angle) between land uses near each well within the sector and the 500-meter circle, by study area

[n/a, not available: Percent of area is the area of the sector compared to the 500-m circle expressed as percent]

\begin{tabular}{|c|c|c|c|c|}
\hline \multirow[b]{2}{*}{ Well number } & \multicolumn{2}{|c|}{ Sheyenne Delta study area } & \multicolumn{2}{|c|}{ Otter Tail Outwash study area } \\
\hline & $\begin{array}{l}\text { Similarity value } \\
\text { between sector and } \\
\text { circle methods }\end{array}$ & $\begin{array}{l}\text { Sector percent of } \\
\text { area of the 500-m } \\
\text { circle }\end{array}$ & $\begin{array}{l}\text { Similarity value } \\
\text { between sector and } \\
\text { circle methods }\end{array}$ & $\begin{array}{l}\text { Sector percent } \\
\text { of area of the } \\
500 \text {-m circle }\end{array}$ \\
\hline 1 & 0.90 & ${ }^{1} 1.00$ & 0.99 & 2.25 \\
\hline 2 & 0.75 & 0.25 & 0.67 & ${ }^{1} 9.00$ \\
\hline 3 & 0.98 & 1.56 & 0.94 & 2.25 \\
\hline 4 & 0.85 & 1.56 & 0.68 & 2.25 \\
\hline 5 & 0.93 & 0.25 & 0.94 & 2.25 \\
\hline 6 & 0.40 & 0.25 & 0.96 & 2.25 \\
\hline 7 & 0.94 & 0.25 & 0.80 & 4.00 \\
\hline 8 & 0.99 & 0.25 & 0.18 & 4.00 \\
\hline 9 & 0.83 & 0.25 & 0.93 & 2.25 \\
\hline 10 & 0.99 & 0.25 & 0.94 & 2.25 \\
\hline 11 & 0.20 & 0.25 & $\mathrm{n} / \mathrm{a}$ & $\mathrm{n} / \mathrm{a}$ \\
\hline 12 & 0.32 & 0.25 & 0.99 & 2.25 \\
\hline 13 & 0.17 & 0.25 & 0.45 & 2.25 \\
\hline 14 & 0.35 & 0.25 & 0.17 & 2.25 \\
\hline 15 & 0.39 & 0.25 & 0.91 & 2.25 \\
\hline 16 & 0.38 & 0.25 & 0.92 & 2.25 \\
\hline 17 & 0.80 & ${ }^{1} 1.00$ & 0.55 & 2.25 \\
\hline 18 & 0.70 & 0.25 & 0.35 & 4.00 \\
\hline 19 & 0.96 & 0.25 & 0.86 & 2.25 \\
\hline 20 & 0.20 & 0.25 & 0.68 & 2.25 \\
\hline 21 & 0.18 & 0.25 & 0.10 & 4.00 \\
\hline 22 & 0.99 & 0.25 & 0.98 & ${ }^{1} 9.00$ \\
\hline 23 & 0.77 & 0.25 & 0.80 & 4.00 \\
\hline 24 & 0.79 & 0.25 & 0.62 & 4.00 \\
\hline 25 & 0.25 & 0.25 & 0.82 & 2.25 \\
\hline 26 & 0.67 & 0.25 & 0.80 & 2.25 \\
\hline 27 & 0.41 & 1.56 & 0.62 & 2.25 \\
\hline 28 & 0.94 & 0.25 & 0.85 & 4.00 \\
\hline 29 & $\mathrm{n} / \mathrm{a}$ & $\mathrm{n} / \mathrm{a}$ & 0.86 & 2.25 \\
\hline 30 & 0.80 & 0.25 & 0.86 & 4.00 \\
\hline Mean & 0.65 & & 0.73 & \\
\hline Median & 0.77 & 0.25 & 0.82 & 2.25 \\
\hline
\end{tabular}

${ }^{1}$ Denotes contributing sector is a circle.

contributing recharge near the well

(Koterba, 1998), and a better relation between land use and water quality because it is not known exactly what area of the 500-m circle actually contributes to water quality at the well.

An analysis of the nitrate concentration highlights the change in the relation between water quality and land use with increasing uncertainly about the area contributing recharge. The Otter Tail Outwash study area offers the opportunity to examine the variability of nitrate conditions within a single aquifer system where many other factors that can affect water quality are fairly constant. A regression analysis was performed relating nitrate concentration to cropland, defined as the sum of the percentages of dryland and irrigated cropland. The nitrate concentration data from 27 wells were log-transformed to linearize the relation. The remaining two wells from the study area were excluded because one well did not have nitrate concentration data and the other because general water chemistry indicated that the well water was a mix of recently recharged water and older water. The results of that regression analysis are presented in table 6 . The results of the regression analysis between nitrate concentration and percent cropland was similar between the two methods (the 
coefficients of the regression lines were comparable), but the significance of the relation changed from a statistically significant $p$-value of 0.05 for the sector method to a statistically nonsignificant $p$-value of 0.29 for the circle method. In this case, the confounding effect of including a much larger area for delineating land use for the recharge area of a well is evident in the poorer relation between nitrate concentration and percentage of cropland land use.

Analysis of pesticide detections to evaluate the usefulness of the two methods for delineating land use near monitoring wells was inconclusive. Pesticide concentrations were low for many samples and many pesticides that were analyzed for were not detected at all for many wells (Cowdery, 1997). Relating pesticide detections to the area of cropland near wells, therefore, was ineffective.

The results of this analysis of contributing areas near shallow monitoring wells compared favorably to a NAWQA study in New Jersey, in which Kauffman and others (2001) investigated the effects of urban, suburban, and agricultural land use on the quality of ground water in an unconsolidated sand and gravel aquifer with a comprehensive model analysis for 70 wells. The effective maximum distance of influence from the New Jersey land-use study wells ranged from 37 to $480 \mathrm{~m}$ with a median distance of 147 $\mathrm{m}$, which is quite comparable to the distance of maximum influence used in the sector method for the Otter Tail Outwash study area (table 2). Also comparable between these two different study areas was the measured maximum ground-water age. Ground water sampled from the New Jersey wells was slightly younger than that measured for the Otter Tail Outwash study (Stoner and others, 1998), but this difference could be explained by the slightly higher average hydraulic conductivity and recharge rate in the New

Table 6. Results of the regression relating land use to nitrate concentrations

\begin{tabular}{cccc}
\hline & \multicolumn{3}{c}{ Regression results } \\
\cline { 2 - 4 } Cropland estimate & Intercept & $\begin{array}{c}\text { Cropland } \\
\text { coefficient }\end{array}$ & $\begin{array}{c}\text { P-value of the } \\
\text { model }\end{array}$ \\
\hline Sector method & -0.560 & 0.0261 & 0.05 \\
Circle method & -0.777 & 0.0259 & 0.29 \\
\hline
\end{tabular}

Jersey aquifer (the Kirkwood-Cohansey aquifer system).

Effective distances of influence reported from these studies derived from a ground-water flow model, such as the sector method, are transferable to aquifers with similar hydrogeologic settings. In vastly differing aquifer settings, it would be more prudent to construct conceptual flow models fitted to local conditions of hydraulic conductivity, porosity, recharge, water-table gradients, and depth to water. Because of the few number of intervening clay lenses observed in drilling cores from the Otter Tail Outwash and Kirkwood-Cohansey aquifers, limited horizontal flow was assumed within these unsaturated zones, further simplifying the links between ground-water quality and activities at land surface. Caution also is suggested for transferring results from these studies to areas of different aquifer materials and conditions that would affect the transport of nitrate and pesticides from land surface to and through shallow ground water. For example, Cowdery (1997) described some differences in the relations between land use and shallow ground-water quality between the Sheyenne Delta and Otter Tail Outwash aquifers attributed to differences in soil and aquifer materials and redox conditions.

At an individual well, factors that can affect water quality include soil characteristics, seasonal recharge, and geology. Several wells in both study areas were sampled repeatedly to assess the variation in water quality occurring through time (fig. 5). On average, nitrate concentrations gener-

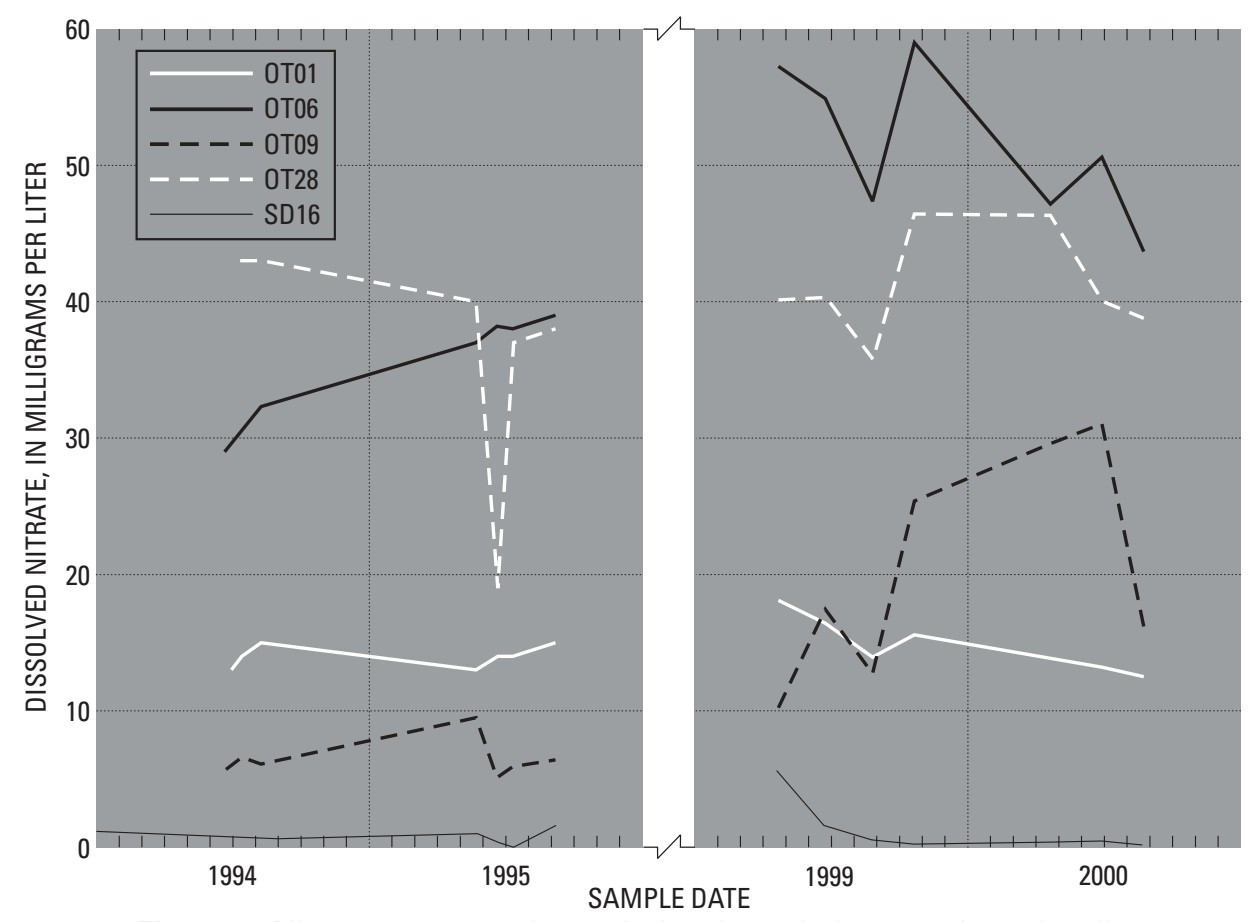

Figure 5. Nitrate concentration variation through time at selected wells. [OTO, Otter Tail Outwash wells; SD, Sheyene Delta well.] 
ally remained high over a 6-year period in the Otter Tail Outwash wells and remained low in the Sheyenne Delta well example. However, nitrate concentration fluctuated widely over periods of months in all of these wells. This fluctuation implies that to characterize the quality of the water withdrawn from a specific well, detailed knowledge on the size of the contributing area and its land use are required along with application rates, timing, and selection of agricultural chemicals; amounts and timing of

\section{SUMMARY}

A component of the National Water Quality Assessment Program is to examine ground-water quality in relation to land use. The objectives of the land-use studies are to assess land-use practices and human and natural factors that affect water quality in recently recharged ground water. The land-use studies concentrate on a targeted land use and hydrogeological conditions. Wells selected for the land-use studies are randomly distributed throughout the targeted land use and hydrogeologic setting specific to the Study Unit.

A critical aspect of data analysis is accurate determination of the characteristic land use that potentially affects the quality of shallow ground water. In the Red River of the North Study Unit, land use at individual wells in two surficial aquifers, the Sheyenne Delta and the Otter Tail Outwash, was determined using two methods. The sector method uses potentiometric surfaces to estimate the direction of ground-water flow and simple flow models to estimate the distance from the well that encompasses contributing recharge to that well. This method produced either a pie-shaped 90-degree section of land upgradient from the well if the direction of ground-water flow was known, or a circle of land surrounding the well if the direction of flow could not be determined. The length of the arm of the sector or radius of the circle ranged from 50 to $200 \mathrm{~m}$ on the basis of particle tracking from bottom of well-screen depths backwards though time to the intersection with the water table. These 90-degree sectors or circles defined the estimated contributing area of recharge for the monitoring well. The circle method of determining the land area affecting a well considers a circular buffer of 500-m radius from the well, which was empirically based on national and regional analysis of statistical correlation between general land use and measured water quality for hundreds of wells in a variety of hydrogeologic and land-use settings across the nation. Generally, the area included in the sectors was sions for effective local land and water management to improve the quality of ground water might best be drawn from these principles of timeintegration of land use and the best available information for delineating the land area most likely to contribute recharge to the monitoring wells. Improved scientific confidence and understanding of relations between land use and quality of ground water may encourage more effective implementation of land and water management for protecting water quality. only 0.25 to 9.0 percent of the area in the $500-\mathrm{m}$ circle. Land use was interpreted from orthorectified photographs and verified in the field by site inspection. Data were compiled by the two methods for 29 wells, each randomly selected near targeted cropland overlying the Sheyenne Delta and Otter Tail Outwash surficial aquifers.

Comparisons of the two methods were made between: (1) land use within the targeted study area and land use near individual wells delineated by each method, and (2) land use within the sectors and the land use within the 500-m circle for each well in each area. The results of the comparisons were: (1) for the Sheyenne Delta and Otter Tail Outwash study areas, the average percentage of land in each of the land-use categories determined by the circle method was more similar to the targeted land use within the general study area than that determined by the sector method; (2) the median similarity value between methods (similarity values range from 0.00 - no similarity to 1.00 complete similarity) was 0.77 within the Sheyenne Delta study area, whereas the median similarity value for wells in the Otter Tail Outwash study areas was slightly greater $(0.82)$.

Where sufficient hydrogeological data are available, the sector method presents a more accurate estimate of the land use affecting an individual monitoring well than the circle method. On the basis of cropland area estimated collectively for each study area by the two methods, the sector method provides a better correlation to nitrate concentrations in the ground water than the circle method. The sector method, or any procedure that incorporates hydrologic sense toward estimating the land area of contributing recharge to a network of monitoring wells should provide more compelling information from which to suggest land and water-management practices for improving quality of shallow ground water.

The distances of land-use influence from wells in this study compared closely with a comprehensive analysis of a similar hydrogeologic setting in the Kirkwood-Cohansey 
aquifer in New Jersey and suggests that these results may be of value for other unconsolidated sand and gravel aquifers with similar hydrogeological characteristics of permeability, water-table slopes, recharge, and depth to water. The additional effort required for estimating the sector delineation of land use and land cover must be weighed against the improved confidence in statistical correlation between land use and the quality of shallow ground water. Relating land use to water quality in a well is complicated by several factors other than land use such as soil character- istics, seasonal recharge, and local geology. Variation in ground-water quality may occur with location, depth, and through time. These factors become more important for more detailed deterministic assessments of land-use effects on the quality of ground water in a specific aquifer. Improved scientific confidence and understanding of relations between land use and quality of ground water may encourage informed implementation of land and water management for protecting water quality.

\section{REFERENCES}

Anderson, J.R., Hardy, E.E., Roach, J.T., and Witmer, R.E., 1976, A land use and land cover classification system for use with remote sensor data: U.S. Geological Survey Professional Paper 964, 28 p.

Cowdery, T.K., 1997, Shallow ground-water quality beneath cropland in the Red River of the North Basin, Minnesota and North Dakota, 1993-95: U.S. Geological Survey Water-Resources Investigations Report 97-4001, 52 p.

Gilliom, R.J., Alley, W.M., and Gurtz, M.E., 1995, Design of the National Water-Quality Assessment Program-Occurrence and distribution of water-quality conditions: U.S. Geological Survey Circular 1112, 40 p.

Kauffman, L.J., Baehr, A.L., Ayers, M.A., Stackelberg, P.E., 2001, Effects of land use and travel time on the distribution of nitrate in the Kirkwood-Cohansey Aquifer System in southern New Jersey: U.S. Geological Survey Water-
Resources Investigations Report 01-4117, 90 p.

Koterba, M.T., 1998, Ground-water data-collection protocols and procedures for the National WaterQuality Assessment ProgramCollection, documentation, and compilation of required site, well, subsurface, and landscape data for wells: U.S. Geological Survey Water-Resources Investigations Report 98-4107, 91 p.

Lorenz, D.L., and Stoner, J.D., 1996, Sampling design for assessing water quality in the Red River of the North Basin, North Dakota, South Dakota, and Minnesota, 1993-95: U.S. Geological Survey Water-Resources Investigations Report 96-4129, 2 plates.

Philip, G.M., and Watson, D.F., 1988, Angle measure compositional differences: Geology, v. 16, p. 976979.

Scott, J.C., 1990, Computerized random site-selection approaches for design of a ground-water-quality sampling network: U.S. Geological Survey Water-Resources
Investigations Report 90-4101, $109 \mathrm{p}$.

Squillace, P.J., and Price, C.V., 1996, Urban land-use study plan for the National Water-Quality Assessment Program: U.S. Geological Survey Open-File Report 96-217, $19 \mathrm{p}$.

Stoner, J.D., Cowdery, T.K., and Puckett, L.J., 1998, Ground-water age dating and other tools used to assess land-use effects on water quality: U.S. Geological Survey Water-Resources Investigations Report 97-4150, 6 p.

Stoner, J.D., Lorenz, D.L., Wiche, G.J., and Goldstein, R.M., 1993, Red River of the North Basin, Minnesota, North Dakota, and South Dakota: Water Resources Bulletin, v. 29, p. 575-615.

U. S. Geological Survey, 1986, Land use and land cover digital data from 1:250,000-and 1:100,000scale maps: U.S. Geological Survey Data User's Guide 4, 40 p. 